\title{
Immunohistochemical Expression of Vimentin, Calponin and HHF-35 in Salivary Gland Tumors
}

\author{
Roberta Barroso CAVALCANTE \\ Fernanda Ferreira LOPES \\ Andréa Soares FERREIRA \\ Roseana de Almeida FREITAS \\ Lélia Batista de SOUZA
}

Department of Oral Pathology, School of Dentistry, Federal University of Rio Grande do Norte, Natal, RN, Brazil

\begin{abstract}
Myoepithelial cells present a complex immunophenotype, with the expression of proteins varying according to the stage of normal or neoplastic differentiation of the cell. In order to evaluate the immunohistochemical markers expressed by these cells, a panel of antibodies composed of vimentin, calponin and HHF-35 was applied to 28 salivary gland tumors. The results demonstrated a higher percent sensitivity of vimentin and calponin compared to HHF-35. However, calponin and HHF-35 presented a focal labeling pattern in contrast with the diffuse distribution of vimentin. The cells predominantly stained by all tested antibodies included nonluminal cells in duct-like and tubular structures, such as those seen in pleomorphic adenomas and adenoid cystic carcinomas, as well as cells in the cords and nests of polymorphous low-grade adenocarcinomas and peripheral cells of sheets and nests of myoepitheliomas. In conclusion, the combination of calponin and vimentin is suggested for the identification of myoepithelial cells in salivary gland tumors.
\end{abstract}

Key Words: myoepithelial cell, salivary gland tumors, vimentin, calponin, HHF-35.

\section{INTRODUCTION}

Salivary gland tumors are characterized by a wide variety of histological types, which makes their classification and diagnosis difficult. This complexity has been attributed to the myoepithelial component of these tumors (1). In view of the difficulty in identifying these myoepithelial cells by routine hematoxylin-eosin staining and even by special techniques, immunohistochemistry has been found to be a useful tool in the distinction of these cells, contributing to an improved differential diagnosis of salivary gland tumors (2-4).

Myoepithelial cells arise from the ectoderm and are located between luminal cells and the basal lamina in normal salivary glands; however, due to their need for contraction these cells present a double phenotype of epithelial and smooth muscle cells (1). Several immunohistochemical markers have been proposed for the identification of myoepithelial cells (5-7). However, as tumors contain myoepithelial cells in different stages of differentiation, the antibodies used show a variable affinity for these cells, especially when comparing myoepithelial cells in normal salivary glands (8-11).

Vimentin has been widely employed as a specific marker for neoplastic myoepithelial cells (12), although this specificity has subsequently been reconsidered (2). At the same time, the literature reported the use of glial fibrillary acid protein and protein S-100 for the identification of these cells, especially in normal salivary glands (13). Various other proteins have currently been employed for the same purpose in salivary gland tumors, including calponin, h-caldesmon, smooth muscle $\alpha$ actin, muscle-specific actin, smooth muscle myosin heavy chain and c-kit $(2,3,8,9,14)$, although with controversial results.

The purose of the present study was to analyze a panel of antibodies (calponin, vimentin and HHF-35) for the identification of myoepithelial cells by comparing

Correspondence: Profa. Dra. Lélia Batista de Souza, Programa de Pós-Graduação em Patologia Oral, UFRN, Departamento de Odontologia, Avenida Salgado Filho, 1787, Lagoa Nova, 59056-000 Natal, RN, Brasil. Tel: +55-84-3215-4132. e-mail: leliasouza@dod.ufrn.br 
their expression pattern between benign (pleomorphic adenoma [PA] and myoepithelioma) and malignant (adenoid cystic carcinoma [ACC] and polymorphous lowgrade adenocarcinoma [PLGA]) salivary gland tumors.

\section{MATERIAL AND METHODS}

For the present sample, 12 cases of PA, 4 cases of myoepithelioma, 8 cases of ACC (4 tubular, 2 solid and 2 cribriform), and 4 cases of PLGA were selected from the archives of the Laboratory of Pathological Anatomy, Department of Oral Pathology, School of Dentistry, Federal University of Rio Grande do Norte, Brazil.

For immunohistochemical analysis, $3-\mu \mathrm{m}$ thick sections were cut from paraffin-embedded blocks and stained by the streptavidin-biotin method as follows: the specimens were deparaffinized, hydrated in a decreasing ethanol series, and treated with $10 \%$ ammonium in $95^{\circ}$ ethanol for removal of formalin pigment. Before incubation with the primary antibodies, endogenous peroxidase was blocked with hydrogen peroxide in methanol and endogenous biotin was blocked according to manufacturer instructions (DakoCytomation, Copenhagen, Denmark), followed by incubation with the anti-vimentin, anti-calponin and anti-HHF-35 antibodies (Table 1). The material was immersed in Tris buffer, $\mathrm{pH}$ 7.4, after each reaction step. Next, the specimens were incubated with the secondary antibody and the streptavidin-biotin complex (SABC) for $30 \mathrm{~min}$ at room temperature and the reaction was developed

Table 1. Description of the antibodies used, clone, antigen retrieval, dilution, time of incubation, and manufacturer.

\begin{tabular}{cccccc}
\hline Antibody & Clone & $\begin{array}{c}\text { Antigen } \\
\text { retrieval }\end{array}$ & Dilution & Incubation & Manufacturer \\
\hline Vimentin & V9 & N/A & $1: 50$ & 120 min & $\begin{array}{c}\text { Dako } \\
\text { Cytomation }\end{array}$ \\
Calponin & CALP & $\begin{array}{c}\text { EDTA } \\
\text { pH 8.0 } \\
\text { Steam 30 min }\end{array}$ & $1: 150$ & Overnight & $\begin{array}{c}\text { Dako } \\
\text { Cytomation }\end{array}$ \\
HHF-35 & HHF-35 & N/A & $1: 50$ & 60 min & $\begin{array}{c}\text { Dako } \\
\text { Cytomation }\end{array}$
\end{tabular}

with diaminobenzidine. The material was then counterstained with Mayer's hematoxylin and coverslipped with Permount.

For immunohistochemical analysis of neoplastic cells, the presence $(+)$ or absence (-) of immunostaining was determined, and the intensity of immunopositivity was classified as strong $(++)$ or weak $(+)$. The distribution pattern (focal or diffuse) as well as the location of stained cells within the tumor arrangement was evaluated.

The results were submitted to descriptive analysis and compared by Fisher's exact test with level of significance set at $5 \%$.

\section{RESULTS}

All immunohistochemical markers tested were effective in the identification of myoepithelial cells, with calponin being expressed in 27/28 (95.43\%) cases, vimentin in 25/28 (89.29\%), and HHF-35 in 21/28 (75\%). Application of Fisher's exact test showed no significant difference between markers (Table 2).

Separate analysis of the intensity of expression revealed a statistically significant difference, with staining for protein HHF-35 being frequently weaker than that observed for vimentin (Table 3). The intensity of expression of the calponin and vimentin markers was similar and predominantly strong.

Vimentin and calponin were expressed in all cases of PA and PLGA, whereas HHF-35 was expressed in only $50 \%$ of PLGA cases and in $67 \%$ of PA cases. In ACCs, calponin was expressed in $100 \%$ of cases, followed by HHF-35 (87.5\%) and vimentin (62.5\%). HHF-35 was the marker least expressed in

Table 2. Immunohistochemical staining of myoepithelial cells in salivary gland tumors.

\begin{tabular}{lccc}
\hline Antibody & \multicolumn{2}{c}{ Staining } & Total \\
\cline { 2 - 3 } & presence & absence & \\
\hline Vimentin & $25(89.29 \%)$ & $3(10.71 \%)$ & $28(100 \%) \mathrm{a}$ \\
Calponin & $27(95.43 \%)$ & $1(3.57 \%)$ & $28(100 \%) \mathrm{a}$ \\
HHF-35 & $21(75.00 \%)$ & $7(25.00 \%)$ & $28(100 \%) \mathrm{a}$
\end{tabular}

Same letter indicate no statistically significant difference by Fisher's exact test $(\alpha=0.05)$. 
cases of myoepithelioma (25\%), with vimentin being expressed in $100 \%$ of cases and calponin in $75 \%$.

The pattern of distribution of vimentin was predominantly diffuse in all tumors studied. In contrast, diffuse positivity for calponin was observed in PAs and myoepitheliomas whereas ACCs and PLGAs presented focal staining. A predominantly focal staining for HHF35 was observed in all tumors studied.

In general, analysis of the localization of protein expression showed that in PAs the immunostaining was concentrated in almost all nonluminal cells (Figs. 1 and 2 ), including polygonal, spindle-shaped, hyaline and plasmacytoid cells, irrespective of tumor arrangement into sheets, nests, cords, tubules or ducts. This staining was more frequent at the periphery of these arrangements than in central areas. Chondroid matrix cells were intensely stained for vimentin. No staining of luminal cells was observed.

Similar to PAs, in myoepitheliomas there was a predominance of positive neoplastic cells located at the periphery of nests and sheets (Fig. 3). Staining for HHF35 was only observed in one of the four cases of myoepithelioma, with a predominance of spindle-shaped cells. In ACCs, immunoreactivity was mainly observed in nests, cells delimiting the pseudocystic spaces of cribriform areas (Fig. 4 ) and, occasionally, in nonluminal cells of tubules and ducts. Focal staining for calponin and HHF-35 was observed in two cases of the solid subtype of ACC (Fig. 5). In PLGAs, positivity for all studied markers, although focal, was mainly observed in nests and cords but also in trabeculae and cells lining the pseudocysts of cribriform areas (Fig. 6).

Table 3. Intensity of immunohistochemical staining in myoepithelial cells of salivary gland tumors.

\begin{tabular}{lccc}
\hline Antibody & \multicolumn{2}{c}{ Staining Intensity } & Total \\
\cline { 2 - 3 } & Strong $(++)$ & Weak $(+)$ & \\
\hline Vimentin & $20(80.00 \%)$ & $5(20.00 \%)$ & $25(100 \%) \mathrm{a}$ \\
Calponin & $18(66.67 \%)$ & $9(33.33 \%)$ & $27(100 \%) \mathrm{ab}$ \\
HHF-35 & $9(42.86 \%)$ & $12(57.14 \%)$ & $21(100 \%) \mathrm{b}$ \\
\hline
\end{tabular}

Different letters indicate statistically significant differences by Fisher's exact test $(\alpha=0.05)$. Vimentin vs. Calponin (aa), Vimentin vs. HHF-35 (ab), Calponin vs. HHF-35 (bb)

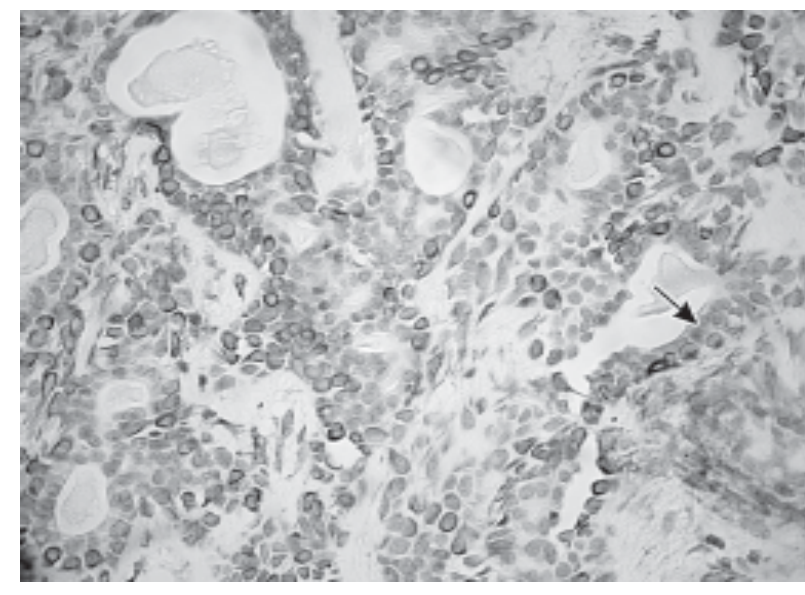

Figure 1. Pleomorphic adenoma: strong citoplasmatic immunoreactivity of vimentin in outer cells of tubular and ductlike structures. The inner cells (arrow) are consistently negative (SABC original magnification $\times 400$ ).

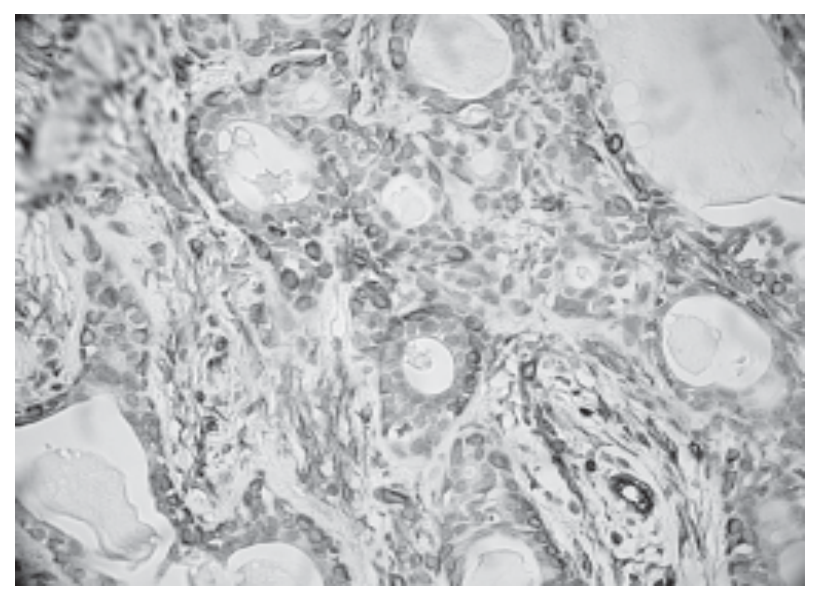

Figure 2. Pleomorphic adenoma with strong immunoreactivity of myoepithelial cells with calponin (SABCoriginalmagnification $\times 400$ ).

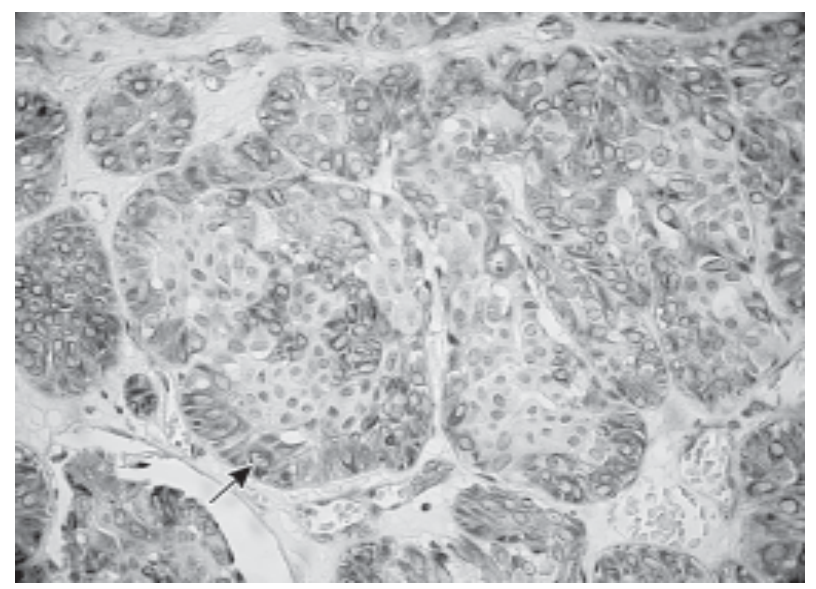

Figure 3. Diffuse staining with vimentin at periphery (arrow) of cell nests in myoepithelioma (SABC original magnification $\times 400$ ). 


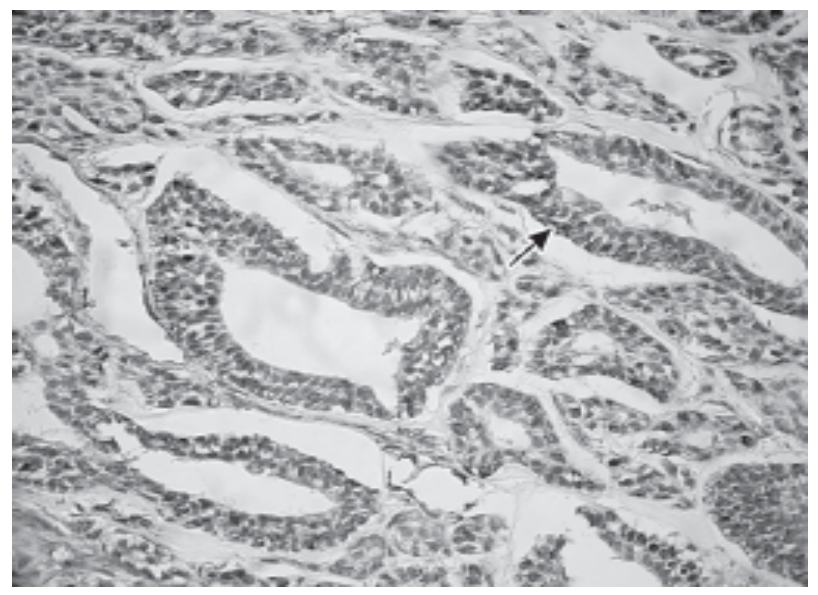

Figure 4. Adenoid cystic carcinoma: luminal cells of the pseudocystic strutures are negative to vimentin, surronded by strongly positive non-luminal cells (arrow) (SABC original magnification $\times 400$ ).

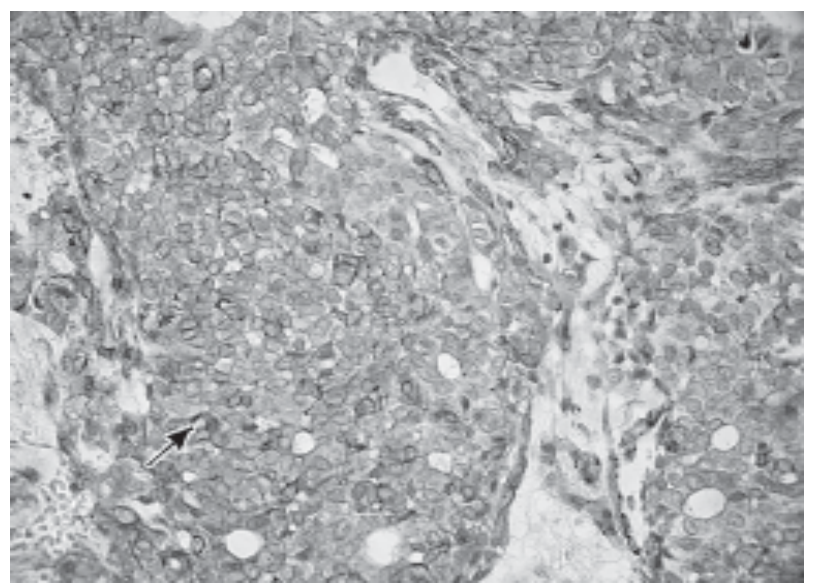

Figure 5. HHF-35 expression in few cells (arrow) in solid subtype adenoid cystic carcinoma (SABC original magnification $\times 400$ ).

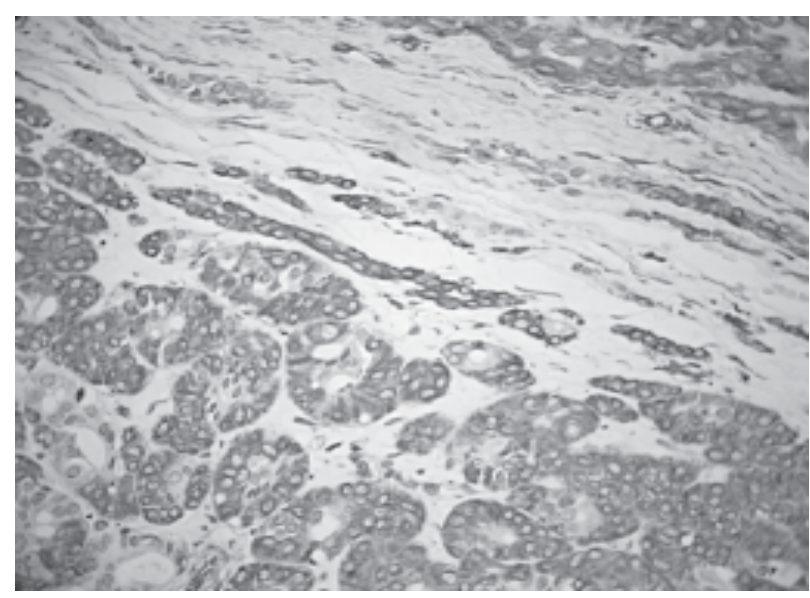

Figure 6. Polymorphous low-gradeadenocarcinomashowing calponin expressed by neoplastic cells (SABC original magnification $\times 400$ ).

\section{DISCUSSION}

The search for diagnostic markers of salivary gland tumors has been the subject of numerous studies investigating antibodies appropriate for the identification of myoepithelial cells. The present study confirms that the results can be analyzed in a general fashion but that the markers are specific for each type of tumor.

With respect to PAs, immunopositivity for vimentin and calponin was observed in almost all cases analyzed. These findings agree with Araújo et al. (2) who reported that myoepithelial cells of PAs present variable vimentin immunopositivity in nonluminal cells of ductal structures and plasmacytoid and spindleshaped cells of nests and cords, and with Savera et al. (9) who showed calponin positivity in 94\% of PAs, with calponin reacting with almost all myoepithelial cells. In general, a predominantly strong expression of all markers was observed in most specimens examined in the present study, located in the cytoplasm of cells arranged in nests, layers of nonluminal cells of tubules and ducts and, occasionally, in peripheral cells of pseudocystic structures. These findings are in agreement with the literature $(2,8,9)$. Specifically, calponin was concentrated in almost all nonluminal cells of tubules or ducts and in polygonal, spindle-shaped, hyaline and plasmacytoid cells, irrespective of tumor arrangement into sheets, nests or cords. Luminal cells were negative for calponin. Similar results have been reported by Furuse et al. (8) who observed calponin expression in PAs including polygonal and plasmacytoid cells, whereas vimentin was expressed in all myoepithelial cells and absent in luminal cells. Devlin and Sloan (14) reported calponin immunopositivity in neoplastic myoepithelium and in some cells in the myxochondroid areas.

In contrast, Ogawa et al. (15) observed calponin positivity in both nonluminal and luminal cells in 12 cases of PA, this staining occurring in less than $25 \%$ to $75 \%$ of cells. These authors suggested that in neoplasms calponin does not exclusively label myoepithelial cells because labeled luminal cells were negative for smooth muscle $\alpha$-actin and h-caldesmon, and that immunoreactivity to calponin may reflect the presence of tonofilaments and/or neural proteins such as S-100 and glial fibrillary acid protein. In another study, Ogawa et al. (5) showed that luminal cells are positive not only for calponin, but also for vimentin. However, we agree with the view of Savera et al. (9), Prasad et al. (4) and 
Furuse et al. (8), who stated that calponin is a marker of myoepithelial cells.

Regarding myoepitheliomas, the studied markers were mainly expressed in peripheral cells of sheets in the case of solid tumors, as well as in spindle-shaped and plasmacytoid cells of nests and cords. Similar findings have been reported by Araújo and Araújo (12), who investigated the immunoexpression of vimentin in three cases. In the same way as in the present study, Araújo and Araújo (12) observed no immunostaining for vimentin in central cells of large tumor masses. HHF-35 was expressed in only one of four myoepithelioma cases, precisely in the case in which spindle-shaped cells predominated. This result agrees with those of Araújo et al. (2), who observed HHF-35 expression only in spindle-shaped cells of myoepitheliomas, and confirms the findings of rare myogenic differentiation of plasmacytoid cells in these tumors (10). Another study (16) demonstrated that in PAs plasmacytoid cells are related to luminal cells and do not originate from myoepithelial cells, expressing no smooth muscle $\alpha$-actin or smooth muscle myosin heavy chain.

The immunopositivity for vimentin and calponin observed in 4 cases of PLGA and the immunopositivity for HHF-35 observed in 2 cases, despite the focal distribution, suggest the eventual presence of myoepithelial cells in this tumor, as demonstrated (17). Araújo et al. $(18,19)$ observed positive staining for HHF-35 in $2 / 6$ and $3 / 30$ cases, respectively, in addition to vimentin expression in all PLGA cases studied. Combining the results of immunohistochemistry and transmission electron microscopy, these authors suggested that myoepithelial cells are not the main component of PLGA and that this tumor probably originates from cells located at the acinar-intercalated duct junction.

However, Prasad et al. (4) reported that the immunoreactivity to myoepithelial cell markers observed in some cases of PLGA is due to the presence of normal salivary acini trapped between tumor cells, as well as of myofibroblasts that aggregate around nests, resembling nonluminal myoepithelial cells. Our results demonstrated the presence of neoplastic cell nests even in the central portions of the tumors that were positive not only for vimentin, but also for calponin and even for HHF-35, although the exact phenotype of these cells could not be determined.

Regarding ACCs, vimentin was expressed in $62.5 \%$ of cases. This result are cosistent with a litera- ture review (20) that stated that vimentin is more frequently present in PLGAs than in ACCs. These authors concluded that vimentin is the only marker able to distinguish between these two neoplasms. However, our results do not support this conclusion.

Still regarding ACCs, HHF-35 immunoreactivity was observed in $87.5 \%$ of cases, with staining being noted in cribriform and tubular areas as well as in solid nests, in agreement with the findings of Araújo et al. (18) who demonstrated HHF-35 staining in the cribriform and tubular subtypes of ACC. However, in contrast to these authors, we also observed HHF-35 positivity, although focal, in peripheral areas in one case of solid ACC. With respect to calponin, our results were similar to those reported by Furuse et al. (8), including calponin positivity in cases of solid ACCs. These findings are expected considering that the cells of solid ACCs are poorly differentiated, possessing the ability to differentiate into ductal/luminal and myoepithelial cells.

Based the present results, it may be concluded that vimentin and calponin are sensitive immunohistochemical markers of myoepithelial cells in salivary gland tumors, exhibiting a predominantly intense expression. Therefore, the combination of calponin and vimentin is suggested for identification of myoepithelial cells in neoplasms since these cells are present in various stages of differentiation.

\section{RESUMO}

As células mioepiteliais apresentam um imunofenótipo complexo, variando a expressão de suas proteínas na dependência do seu estágio de diferenciação normal ou neoplásico. Com o objetivo de avaliar comparativamente marcadores imuno-histoquímicos para estas células, um painel de anticorpos composto pela vimentina, calponina e HHF-35 foi aplicado em 28 tumores de glândulas salivares. Os resultados demonstraram que a vimentina e a calponina foram percentualmente mais sensíveis que o HHF-35; entretanto, a calponina e o HHF-35 apresentaram padrão de distribuição focal diferentemente da distribuição difusa da vimentina. As células predominantemente marcadas, por todos os anticorpos utilizados, foram as não luminais presentes nas estruturas ductiformes e tubulares, vistas no adenoma pleomórfico e no carcinoma adenóide cístico, bem como as células dos cordões e ninhos dos adenocarcinomas polimorfo de baixo grau e periferia de lençóis e ninhos dos mioepiteliomas. Em conclusão, sugere-se que se faça associação da calponina com vimentina para identificação de células mioepiteliais em neoplasias de glândula salivar.

\section{ACKNOWLEDGEMENTS}

The authors would like to acknowledge CAPES and CNPq for financial support. 


\section{REFERENCES}

1. Ellis GL, Auclair PL. Tumors of the salivary glands. In: Atlas of tumor pathology. Fascicle 17. Washington, DC: Armed Forces Institute of Pathology; 1996:228-245.

2. Araújo VC, Sousa SOM, Carvalho YR, Araújo NS. Application of immunohistochemistry to the diagnosis of salivary gland tumors. Appl Immuno Mol Morphol 2000;8:195-202.

3. Epivatianos A, Poulopoulos A, Dimitrakopoulos I, Andreadis D, Nomikos A, Vlahou S, Papazoglou G, Barbatis C.Application of alpha-smooth muscle actin and c-kit in differential diagnosis of adenoid cystic carcinoma from polymorphous low-grade adenocarcinoma. Oral Oncol 2007;43:67-76.

4. Prasad AR, Savera AT, Gown AM, Zarbo RJ. The myoepithelial immunophenotype in 135 benign and malignant salivary gland tumors others than pleomorphic adenoma. Arch Pathol Lab Med 1999;123:801-806.

5. Ogawa Y. Immunocytochemistry of myoepithelial cells in the salivary glands. Prog Histochem Cytochem 2003;38:343426.

6. Furuse C, Cury PR, de Araujo NS, de Araujo VC. Application of two different clones of vimentin to the diagnosis of salivary gland tumors. Appl Immunohistochem Mol Morphol 2006;14:217-219.

7. de Araujo VC, Altemani A, Furuse C, Martins MT, de Araújo NS. Immunoprofile of reactive salivary myoepithelial cells in intraductal areas of carcinoma ex-pleomorphic adenoma. Oral Oncol 2006;42:1011-6.

8. Furuse C, Machado de Sousa SO, Nunes FD, Gallottini de Magalhaes MH, Cavalcanti de Araújo V. Myoepithelial cell markers in salivary gland neoplasms. Int J Surg Pathol 2005; 13:57-65.

9. Savera AT, Gown AM, Zarbo RJ. Immunolocalization of three novel smooth muscle-specific proteins in salivary gland pleomorphic adenoma: assessment of the morphogenetic role of myoepithelium. Mod Pathol 1997;10:1093-1100.

10. Takai Y, Dardick I, Mackay A, Burford-Mason A, Mori M. Diagnostic criteria for neoplastic myoepithelial cells in pleomorphic adenomas and myoepitheliomas. Immunocytochemical detection of muscle-specific actin, cytokeratin 14, vimentin, and glial fibrillary acidic protein. Oral Surg Oral Med Oral Pathol Oral Radiol Endod 1995;79:330-341.
11. Beltran D, Faquin WC, Gallagher G, August M. Selective immunohistochemical comparison of polymorphous lowgrade adenocarcinoma and adenoid cystic carcinoma. J Oral Maxillofac Surg .2006;64: 415-423.

12. Araújo VC, Araújo NS. Vimentin as a marker of myoepithelial cells in salivary gland tumors. Eur Arch Otorhinolaryngol 1990;247:252-255.

13. Okura M, Hiranuma T, Tominaga G, Yoshioka H, Aikawa T, Shirasuna K, Matsuya T. Expression of S-100 protein and glial fibrillary acidic protein in cultured submandibular gland epithelial cells and salivary gland tissues. Histogenetic implication for salivary gland tumors. Am J Pathol 1996;148:17091716.

14. Devlin H, Sloan P. Immunolocalization of cartilage-derived retinoic acid-sensitive protein in pleomorphic adenoma of parotid salivary gland. J Oral Pathol Med 2001;30:87-90.

15. Ogawa $\mathrm{Y}$, Toyosawa $\mathrm{S}$, Ishida $\mathrm{T}$, Ijuhin N. Keratin $14 \mathrm{immu-}$ noreactive cells in pleomorphic adenomas and adenoid cystic carcinomas of salivary glands. Virchows Arch 2000;437:5868

16. Ogawa Y, Kishino M, Atsumi Y, Kimoto M, Fukuda Y, Ishida $\mathrm{T}$, Ijuhin N. Plasmacytoid cells in salivary-gland pleomorphic adenomas: evidence of luminal cell differentiation. Virchows Arch 2003;443:625-634.

17. Gnepp DR, Chen JC, Warren C. Polymorphous low grade adenocarcinoma of minor salivary gland: an immunohistochemical and clinicopathologic study. Am J Surg Pathol 1990;12:461-468.

18. Araújo VC, Carvalho YR, Araújo NS. Actin versus vimentin in myoepithelial cells of salivary gland tumors. A comparative study. Oral Surg Oral Med Oral Pathol Oral Radiol Endod 1994;77:387-391.

19. Araújo VC, Sousa SOM, Jaeger MM, Loyola A, Crivelini M, Araújo N. Characterization of cellular component of polymorphous low-grade adenocarcinoma by immunohistochemistry and electron microscopy. Oral Oncol 1999;35:164-172.

20. Darling MR, Schneider JW, Phillips VW. Polymorphous lowgrade adenocarcinoma and adenoid cystic carcinoma: a review and comparison of immunohistochemical markers. Ora Oncol 2002;38:641-645. 